\title{
PENERAPAN METODE RESITASI DALAM MENINGKATKAN HASIL BELAJAR SISWA
}

\author{
Husain Tanaiyo ${ }^{1)}$ Rosman Ilato ${ }^{2)}$, Rusli Isa ${ }^{3)}$ \\ Universitas Negeri Gorontalo \\ Email: husain@gmail.com
}

\begin{abstract}
ABSTRAK
Tujuan penelitian ini adalah untuk Meningkatkan Hasil Belajar Siswa Dengan Menerapkan Metode Resitasi Dalam Meningkatkan Hasil Belajar Siswa Pada Mata Pelajaran IPS Terpadu Kelas VIII-2 Di SMP Negeri 2 Telaga Kabupaten Gorontalo". Pendekatan yang digunakan dalam penelitian ini adalah pendekatan kuantitatif dengan metode penelitian tindakan kelas yang dilaksanakan sebanyak 2 siklus dan menggunakan metode resitasi. Adapun langkah- langkah metode reistasi terdiri dari: (1) perencanaan, (2) pelaksanaan, (3) pengamatan dan evaluasi, dan (4) analisis dan refleksi. Teknik pengumpulan data menggunakan lembar observasi dan tes hasil belajar. Tehnik analisis data menggunakan kriteria penilaian. Hasil penelitian menunjukan bahwa penerapan metode resitasi dapat meningkatkan hasil belajar siswa. Dilihat dari observasi awal dengan jumlah 25 siswa. Siswa yang memperoleh nilai ketuntasan berjumlah 7 orang atau $28 \%$, kemudian meningkat pada siklus 1 sebanyak 16 0rang siswa atau 64\%, dan meningkat pada siklus 2 menjadi 22 Orang siswa atau 88\%.
\end{abstract}

Kata Kunci: Hasil Belajar, Metode Resitasi.

\begin{abstract}
The purpose of this study is "To Improve Student Learning Outcomes By Implementing Recitation Methods in Improving Student Learning Outcomes in Integrated Social Sciences Subjects Class VIII-2 in SMP Negeri 2 Telaga, Gorontalo Regency". The approach used in this research is a quantitative approach with a class action research method carried out by 2 cycles and using recitation methods. The steps of the method of reistation consist of: (1) planning, (2) implementation, (3) observation and evaluation, and (4) analysis and reflection. Data collection techniques using observation sheets and learning outcomes tests. Data analysis techniques use assessment criteria. The results showed that the application of the recitation method could improve student learning outcomes. Judging from the initial observations with the number of 25 students. Students who get mastery scores are 7 people or $28 \%$, then increase in cycle 1 by 16 students or $64 \%$, and increase in cycle 2 to be 22 students or $88 \%$.
\end{abstract}

Keywords: Learning Outcomes, recitation methods 


\section{PENDAHULUAN}

Berdasarkan Observasi Di SMP Negeri 2 Telaga diperoleh data sebagai berikut: Kurangnya pemahaman sebagian siswa pada saat proses belajar mengajar akibatnya mereka tidak dapat menyelesaikan masalah atau soal-soal yang diberikan oleh guru serta kurangnya partisipasi sebagian siswa dalam proses pembelajaran. Suasana pembelajaran di dalam kelas tidak kondusif karena siswa tidak memperhatikan penjelasan materi yang disampaikan oleh guru. Adapun kurang tersedianya sarana penunjang proses pembelajaran mengakibatkan siswa tidak termotivasi untuk belajar. Kurangnya minat baca siswa. Siswa tidak mampu mendeskripsikan materi pembelajaran. Akibatnya banyak siswa yang belum mencapai hasil belajar sesuai dengan harapan.

Dari penilaian hasil belajar siswa di peroleh data, yaitu dari 25 siswa hanya 7 siswa (28\%) yang mencapai kkm, sedangkan 18 siswa (72\%) belum mencapai kkm yang ditetapkan oleh sekolah yaitu 75 . Rendahnya perolehan hasil belajar pada mata pelajaran IPS Terpadu pada siswa kelas VIII-2 Di SMP Negeri 2 Telaga, menunjukkan adanya indikasi terhadap rendahnya Hasil belajar siswa. Untuk mengetahui mengapa hasil belajar siswa tidak seperti yang diharapkan, tentu guru perlu merefleksikan diri untuk dapat mengetahui penyebab ketidak berhasilan siswa dalam pembelajaran, dengan memilih model pembelajaran yang tepat sehingga dapat meningkatkan hasil belajar siswa. Berdasarkan hal tersebut, salah satu upaya yang perlu diterapkan agar dapat mengatasi problematika siswa dalam rangka peningkatan hasil belajar siswa yaitu dengan penerapan metode Resitasi. Metode ini merupakan Metode pembelajaran yang dapat mendorong siswa untuk meningkatkan inisiatif dan partisipasinya, siswa tidak mendominasi pembicaraan atau diam sama sekali, siswa menjadi aktif dalam kegiatan pembelajaran, meningkatkan kemampuan siswa dalam berkomunikasi (aspek berbicara), mengajarkan siswa untuk menghargai pendapat orang lain.

\section{KAJIAN TEORITIS}

Tinjauan Tentang Hasil Belajar Hasil belajar menurut Gagne \& Briggs dalam Suprihatiningrum (2016:37) adalah kemampuan-kemampuan yang dimiliki siswa sebagai akibat perbuatan belajar dan dapat diamati melalui penampilan siswa. Menurut Bloom (dalam Suprijono 2013: 6), hasil belajar mencakup kemampuan kognitif, afektif dan psikomotorik. Sedangkan menurut Lindgren (Suprijono, 2013: 7) hasil pembelajaran meliputi kecakapan, informasi, pengertian dan sikap. Yang harus diingat, hasil belajar adalah perubahan perilaku secara keseluruhan bukan hanya salah satu aspek potensi kemanusiaan saja. Artinya, hasil pembelajaran yang dikategorisasi oleh para pakar pendidikan sebagaimana tersebut di atas tidak di lihat secara fragmentaris atau terpisah, melainkan komprehensif. Sudjana (2009:3) hasil belajar merupakan perubahan tingkah laku sebagai hasil belajar dalam pengertian yang lebih luas mencakup bidang kognitif, afektif, dan psikomotorik. Tinjauan Tentang Metode Resitasi

Resitasi adalah penyajian kembali atau penimbulan kembali sesuatu yang sudah dimiliki, diketahui atau dipelajari. Metode ini sering disebut metode pekerjaan rumah (Ramayulis, 2001:164), Tugas-tugas yang dilaksanakan oleh peserta didik Dapat 
dilakukan di dalam kelas, di halaman sekolah, di laboratorium, diperpustakaan, di bengkel, atau di mana saja asal tugas tersebut dapat diselesaikan (Roestiyah, 2001:96). Metode resitasi sebenarnya metode yang penekanannya dilakukan pada jam pelajaran yang berlangsung dimana peserta didik diberi tugas untuk mencari informasi atau faktafakta berupa data yang dapat ditemukan di pusat sumber belajar (Basyarudin, 2002:96). Namun, pelaksanaan dapat dilaksanakan dimana saja asal tugas tersebut bisa diselesaikan.

\section{METODE}

Penelitian tindakan kelas ini dilaksanakan di SMP Negeri 2 Talaga Kabupaten Gorontalo Lokasi tersebut pada beberapa alasan bahwa objek tersebut sesuai dengan tujuan penelitian, selain itu data yang digunakan sebagai bahan penelitian cukup memadai dan mudah memperolehnya, baik dari segi waktu, biaya dan tenaga yang diperlukan. Subjek dari penelitian adalah kelas VIII- 2 yang berjumlah 25 orang.

Jika tahap perencanaan sudah matang maka tahap berikutnya adalah pelaksanaan tindakan dengan menggunakan metode Resitasi adapun langkah-langkah pada tahap ini adalah:

\section{Kegiatan awal}

1. Mengucapkan salam.

2. Mengecek kehadiran siswa sambil mengenal siswa.

3. Meminta siswa mengeluarkan buku teks dan buku tulis, serta menyiapkan peralatan tulis, seperti kertas dan strabilo/ penanda lainnya untuk menandai bagian terpenting dalam teks.

4. Menjelaskan pada siswa kegiatan pembelajaran yang akan dilakukan dengan menggunakan metode Resitasi

5. Memberikan penjelasan mengenai materi yang akan dibahas dan tujuan pembelajaran yang akan dicapai

6. Memberikan pertanyaan interaktif yang berkenaan dengan materi yang akan disampaikan

7. Melakukan pretes

\section{Kegiatan Inti}

1. Menerangkan materi yang berkaitan dengan materi yang akan digunakan dalam pembelajaran yakni Ips Terpadu.

Dengan materi sebagai berikut:

Perdagangan dan perdagangan Antar daerah/ Antar pulau.

Kemudian menjelaskan sub-sub materi tersebut.

a) Pengertian perdagangan dan perdagangan Antar Pulau.

b) Tujuan perdagangan Antar Pulau.

c) Faktor pendorong dan manfaat perdagangan Antar Pulau/ Antar Daerah.

2. Guru membagikan LKS yang berisi pertanyaan atau masalah dan siswa membaca, memikirkan dan mengerjakan LKS, menjawab pertanyaan, menyelesaikan masalah secara mandiri, serta membuat catatan untuk dibawa kekelompok diskusi 
(Think).

3. Siswa membentuk kelompok 3-5 orang secara heterogen.

4. Siswa menuju kelompoknya, untuk berkolaborasi membahas jawaban dari pertanyaan guru berdasarkan jawaban yang telah mereka peroleh secara mandiri (Talk).

5. Guru memanggil kelompok tertentu untuk mempresentasikan hasil pekerjaannya di depan kelas dan kelompok lain untuk menanggapinya,kegiatan tersebut di lanjutkan sampai beberapa kelompok siswa, di sesuaikan dengan waktu yang tersedia.

6. Setiap siswa mengkotruksi atau menulis kembali hasil diskusi pada lembar kerja yang disediakan (Write).

7. Memberikan penghargaan pada hasil belajar siswa, baik individu maupun kelompok.

\section{Kegiatan Penutup}

1. Bertanya jawab tentang hal-hal yang belum dipahami siswa.

2. Menyimpulkan pembelajaran dan memberikan tindak lanjut.

3. Salam.

Pada pelaksanaan penelitian tindakan kelas ini digunakan beberapa teknik pengumpulan data yang terdiri dari:

1. Observasi

Teknik observasi dilakukan melalui pengamatan secara umum terhadap lokasi penelitian yang berhubungan dengan kegiatan pembelajaran yang dilakukan.

2. Lembar pengamatan guru

3. Lembar pengamatan guru adalah lembar kerja yang berfungsi untuk mengobservasi dan mengukur tingkat keberhasilan atau ketercapaian seorang guru dalam tujuan pembelajaran pada kegiatan belajar mengajar dikelas.

4. Lembar kerja siswa

5. Lembar kerja siswa adalah lembar penilaian yang berfungsi untuk mengobservasi dan mengukur tingkat keberhasilan atau ketercapaian siswa dalam tujuan

\section{Dokumentasi} pembelajaran pada kegiatan belajar mengajar dikelas.

Dokumentasi yang dimaksud dalam bentuk foto selama pelaksaan penelitian. Ini diperlukan sebagai bukti fisik dalam penelitian.

\section{HASIL}

\section{Hasil Pengamatan Kegiatan Guru Siklus I}

Pengamatan proses pembelajaran dilakukan oleh guru mitra yang bertindak sebagai pengamat dalam penelitian ini yang terdiri dari 22 aspek antara lain: 9 aspek (36\%) mencapai kriteria sangat baik, 8 aspek (32\%) mencapai kriteria baik, dan 5 aspek (20\%) mencapai kriteria cukup, 3 aspek (12\%) mencapai criteria kurang. 
Hasil pengamatan guru yang memperoleh kriteria sangat baik ada 9 aspek antara lain: 1) Kesiapan perangkat pembelajaran (RPP, Buku penunjang), 2) Memeriksa ruang kelas serta kesiapan siswa, 3)Mengucapkan salam dan berdoa, 4) Menyiapkan kompetensi dan tujuan pembelajaran, 5) Bahan ajar dan langkah-langkah sesuai RPP, 6) Guru membimbing siswa dalam penggunaan lembar kegiatan siswa, 7) Melakukan refleksi, 8) Memberikan evaluasi, 9) Menutup pembelajaran. Selanjutnya yang memperoleh kriteria baik ada 8 aspek yang antaralain: 1) fase pemberian tugas, 2) fase pelaksanaan tugas, 3) Memberikan apersepsi dan memotivasi siswa, 4) Penyajian sesuai dengan urutan materi, 5) Memiliki wawasan luas dan penguasaan dalam menyampaikan bahan ajar/materi, 6) Penyajian bahan ajar sesuai dengan tujua/indikator yang telah ditetapkan, 7) Guru membimbing siswa dalam penggunaan metode pembelajaran resitasi, 8) Guru mengajukan informasi kepada siswa tentang materi pembelajaran

Selanjutnya yang memperoleh kriteria cukup ada 5 aspek yang diantranya: 1) fase evaluasi tugas, 2) Memiliki keterampilan dalam menanggapi dan merespon pertanyaan siswa, 3) Ketepatan dalam menggunakan alokasi waktu yang disediakan, 4) Menguasai kelas, 5) Mengevaluasi hasil belajar tentang materi yang dipelajari dan mempresentasikan hasil kerjanya. Sedangkan yang memperoleh criteria kurang ada 3 aspek yang diantaranya: 1) Kejelasan dalam menjelaskan bahan ajar/materi, 2) Kejelasan dalam memberikan contoh, 3) Guru memberikan penghargaan pada hasil belajar siswa.

\section{Hasil Pengamatan Kegiatan Siswa Siklus I}

Pengamatan kegiatan siswa juga dilakukan oleh guru mitra yang terdapat 20 aspek antara lain: 7 aspek (35\%) mencapai kriteria sangat baik, 6 aspek (30\%)mencapai kriteria baik, 5 aspek (25\%) mencapai kriteria cukup, dan 2 aspek (10\%) mencapai criteria kurang.

Hasil pengamatan kegiatan siswa diatas yang memperoleh kriteria sangat baik ada 7 aspek antara lain:1) Kesiapan siswa menerima pembelajaran, 2) Siswa mampu menjawab pertanyaan apersepsi, 3) Aktif bertanya saat proses pembelajaran, 4) Adanya interaksi positif antar guru dan siswa, 5) Siswa aktif dalam menerima materi yang diajarkan, 6) Siswa merasa termotivasi dalam mengikuti pelajaran, 7) Siswa secara aktif membuat rangkuman. Selanjutnya yang memperoleh kriteria baik ada 6 aspek antara lain: 1) fase pemberian, 2) fase pelaksanaan tugas, 3) Mendengar dan memahami kompetensi yang hendak dicapai, 4) Memperhatikan ketika dijelaskan, 5) Memperhatikan atau mendengarkan penjelasan teman/guru dengan sungguh-sungguh, 6) Siswa tampak tekun mempelajari sumber belajar yang ditentukan oleh guru.Selanjutnya yang memperoleh kriteria cukup ada 5 aspek antara lain: 1) fase evaluasi tugas, 2) Aktif dalam mengikuti kegiatan pembelajaran, seperti bertanya, berdiskusi, 3) Memberikan jawaban dan menyatakan ide, pendapat, 4) Adanya interaksi positif antar siswa dengan media dan metode pembelajaran resitasi yang digunakan guru, 5) Siswa tertarik pada materi yang disajikan dengan metode pembelajaran resitasi. Sedangkan yang memperoleh criteria kurang diantaranya: 1) Siswa terlibat aktif dalam proses pembelajaran, 2) Siswa mampu menjawab pertanyaan yang diajukan oleh guru.

\section{Hasil Belajar Siswa Siklus I}


Pengukuran terhadap hasil belajar siswa pada siklus I dilakukan dengan menggunakan tes (evaluasi) tindakan secara tertulis. Tes yang diberikan pada siswa untuk mengemukakan tindakan pada siklus I sebanyak 5 butir soal essay, dengan bobot maksimal capaian 100. Dari hasil analisis tes pada siklus I menunjukan bahwa dari 25 orang siswa yang ditindaki, 16 orang siswa (64\%) memperoleh nilai 75 keatas dan 9 orang siswa (36\%) memperoleh nilai kurang dari 75 dengan nilai rata-rata kelas 76,96\%. Hasil ini telah mulai mengalami peningkatan terhadap hasil belajar yang sebelumnya.

\section{Hasil Pengamatan Kegiatan Guru Siklus II}

Pengamatan kegiatan guru pada siklus II juga dilakukan oleh guru mitra yang terdapat 25 aspek yang harus diterapkan oleh guru serta perlu adanya penekanan pada beberapa aspek yang belum dilakukan secara maksimal pada penerapan yang sebelumnya.

Hasil pengamatan kegiatan guru pada siklus II mencapai 13 aspek dengan kriteria sangat baik (52\%), 11 aspek dengan kriteria baik (44\%), 1 aspek dengan criteria cukup (4\%). Hasil pengamatan guru yang memperoleh sangat baik berjumlah 13 aspek diantaranya: 1) Kesiapan perangkat pembelajaran (RPP, buku penunjang, Dll), 2) Kesiapan Memeriksa ruang kelas serta kesiapan siswa, 3) Mengucapkan salam dan berdoa, 4) Menyampaikan kompetensi dan tujuan pembelajaran, 5) fase pemberian tugas, 6) fase pelaksanaan tugas, 7) Bahan ajar dan langkah-langkah sesuai dengan RPP, 8) Penyajian bahan ajar sesuai dengan tujuan /indicator yang telah ditetapkan, 9) Guru mengajukan informasi kepada siswa tentang materi pembelajaran, 10) Guru membimbing siswa dalam penggunaan lembar kegiatan siswa, 11) Melakukan refleksi, 12) Memberikan evaluasi, 13) Menutup pembelajaran. Selanjutnya yang memperoleh kriteria baik ada 11 aspek antaralain: 1) fase evaluasi tugas, 2) Memberikan apersepsi dan memotivasi siswa, 3) Kejelasan dalam menjelaskan bahan ajar/materi, 4) Penyajian sesuai dengan urutan materi, 5) Kejelasan dalam memberikan contoh, 6) Memiliki wawasan luas dan penguasaan dalam menyampaikan bahan ajar/materi, 7) Ketepatan dalam menggunakan alokasi waktu yang disediakan, 8) Guru membimbing siswa

dalam penggunaan metode pembelajaran resitasi, 9) Menguasai kelas, 10) Mengevaluasi hasil belajar tentang materi yang dipelajari dan mempresentasikan hasil kerjanya, 11) Guru memberikan penghargaan pada hasil belajar siswa. Selanjutnya yang memperoleh kriteria cukup ada 1 aspek diantaranya: 1) Memiliki keterampilan dalam menanggapi dan merespon pertanyaan siswa,

\section{Hasil Pengamatan Kegiatan Siswa Siklus II}

Pengamatan siswa pada siklus II juga dilakukan oleh guru mitra sama halnya dengan siklus I, keberhasilan tindakan pada siklus II untuk pengamatan kegiatan siswa juga dilakukan oleh guru mitra selaku pengamat yang meliputi 20 aspek seperti pada siklus I. Hasil pengamatan kegiatan siswa pada siklus II ini yang memperoleh kriteria sangat baik berjumlah 11 aspek (55\%), selanjutnya yang memperoleh kriteria baik berjumlah 6 aspek (30\%), selanjutnya yang memperoleh criteria cukup 3 aspek (15\%).

Hasil pengamatan kegiatan siswa yang memperoleh kriteria sangat baik berjumlah 11 aspek antara lain: 1) Kesiapan siswa menerima pembelajaran, 2) Siswa mampu menjawab pertanyaan apersepsi, 3) fase pemberian tugas, 4) fase pelaksanaan tugas, 5) 
Aktif bertanya saat proses pembelajaran, 6) Adanya interaksi positif antar guru dan siswa, 7)Siswa aktif dalam menerima materi yang diajarkan, 8) Siswa merasa termotivasi dalam mengikuti pelajaran, 9) Adanya interaksi positif antar siswa dengan media dan metode pembelajaran resitasi yang digunakan guru, 10) Siswa tertarik pada materi yang disajikan dengan metode pembelajaran resitasi, 11) Siswa secara aktif membuat rangkuman.Selanjutnya yang memperoleh kriteria baik berjumlah 6 aspek antaralain: 1) fase evaluasi tugas, 2) Mendengar dan memahami kompetensi yang hendak dicapai, 3) Memperhatikan ketika dijelaskan, 4) Siswa terlibat aktif dalam proses pembelajaran, 5) Memperhatikan atau mendengarkan penjelasan teman/guru dengan sungguh-sungguh, 6) Siswa tampak tekun mempelajari sumber belajar yang ditentukan oleh guru. Sedangkan yang memperoleh kriteria cukup ada 3 aspek diantaranya: 1) Aktif dalam mengikuti kegiatan pembelajaran, seperti bertanya, berdiskusi, 2) Memberikan jawaban dan menyatakan ide, pendapat, sanggahan, masukan atau saran, 3) Siswa mampu menjawab pertanyaan yang diajukan oleh guru.

\section{Hasil Belajar Siswa Siklus II}

Pada hasil siklus II dilaksanakan untuk menyempurnakan tindakan yang dilakukan pada siklus I. Ini menandakan bahwa aspek-aspek yang belum dilaksanakan secara optimal pada siklus I telah lebih dimaksimalkan pada siklus II yang menggunakan dengan tes tertulis soal essay. Soal essay tersebut berjumlah 5 butir soal dengan skor maksimum yang dapat dicapai oleh siswa adalah 100. Dari hasil analisis tes pada siklus II menunjukan bahwa dari 25 orang siswa yang dikenai tindakan ada 21 orang siswa (84\%) memperoleh nilai 75 ke atas dan 4 orang siswa (16\%) memperoleh nilai kurang dari 75 kebawah dengan nilai rata-rata kelas mencapai $83,6 \%$ dari rata-rata daya serap mencapai 83,6 .

\section{SIMPULAN}

Penerapan Metode Resitasi pada mata pelajaran IPS terpadu Kelas VIII-2 Di SMP Negeri 2 Telaga Kabupaten Gorontalo dapat meningkatkan hasil belajar siswa, yang hal ini terbukti dengan meningkatnya jumlah siswa yang memperoleh nilai ketuntasan dari $28 \%$ saat observasi awal menjadi $64 \%$ hasil siklus I dan meningkat lagi menjadi $88 \%$ hasil siklus.

\section{DAFTAR PUSTAKA}

Jamil, Suprihatiningrum. 2016. Strategi Pembelajaran Teori \& Aplikasi. Jogjakarta: ARRUZZ MEDIA.

Ramayulis. 2001.Metodologi Pengajaran Agama Islam. Jakarta:Kalam Mulia. Roestiyah N.K, 2001. Strategi Belajar Mengajar. Jakarta: PT. Rineka Cipta Sudjana, Nana. 2009. Penilaian Hasil Proses Belajar Mengajar. Bandung: PT Remaja Rosdakarya

Suprijono, Agus. 2013.Cooperative Learning Teori \& Aplikasi. Yogyakarta:Pustaka Pelajar. 